"Volume 14, No. 1, Juni 2020"

\title{
ZAKAT DAN KESEJAHTERAAN MUSTAHIQ DI BAZNAS BANYUWANGI
}

\author{
Oleh: \\ Subaidi \& Subyanto \\ Universitas Ibrahimy Situbondo, Indonesia \\ subaidishalli@yahoo.co.id \& zsubyanto65@gmail.com
}

\begin{abstract}
:
Zakat has a very important role in improving the welfare of society, especially the mustahiq (zakat recipients). Because zakat can consider their real needs in utilizing zakat funds for increasing welfare and reduce poverty so that the mustahiq is expected to be a muzakki (zakat provider). But the purpose of zakat to improve mustahiq welfare is difficult to realize if there is no active role from the muzakki and zakat managers. Muzakki must be aware that their goal of zakat is not only to abort their obligations but also to the wider interests of reducing poverty. Distribution of zakat by BAZNAS (National Zakat Agency) of Banyuwangi in improving mustahiq carried out productively by helping Mustahiq to improve welfare both individually and in groups through entrepreneurial activities that can support the economic sustainability of musatahiq. The role of BAZNAS (National Zakat Agency) of Banyuwangi in improving mustahiq welfare has been carried out by providing information for the society, especially people who can pay zakat (muzakki) about the importance of zakat which has great potential in assisting government programs in reducing poverty.
\end{abstract}

Keywords: Zakat, Mustahiq, Baznas, Kesejahteraan Ekonomi

\section{A. Pendahuluan}

Pada zaman modern banyak terjadi ketimpangan-ketimpangan dan ketidakmerataan, terutama dalam masalah sosial ekonomi. Banyak orangorang kaya yang semakin kaya dan tidak sedikit pula orang-orang miskin yang semakin miskin terpuruk pada kemiskinannya, diantaranya karena adanya ketidakmerataan dalam penyaluran zakat, baik zakat secara umum maupun zakat secara khusus.

Pada tataran demokrafis dan kultural, umat muslim Indonesia sebenarnya memiliki potensi strategis yang layak dikembangkan menjadi salah satu instrument pemerataan pendapatan yaitu konsumsi Zakat, Infak dan Sadakah (ZIS), kewajiban zakat dan dorongan berinfak dan bersadakah di jalan Allah telah mengakar kuat dalam tradisi masyarakat

$$
\begin{array}{l|l}
\text { JURNAL LISAN AL-HAL } & 137
\end{array}
$$


muslim. ${ }^{1}$ Dengan demikian mayoritas penduduk Indonesia, secara ideal bisa terlibat dalam mekanisme pengelolaan zakat, secara hipotetif, sebenarnya zakat berpotensi memengaruhi aktivitas ekonomi Nasional. Dana zakat dapat dipungut dari mereka yang kelebihan harta benda yang kemudian diberikan kepada mereka yang kekurangan. Namun begitu, tidak bermaksud ingin memiskinkan orang yang kaya karena di dalam penyaluran zakat ada batas maksimal dan hanya sebagian kecil harta yang diambil dari orang kaya. ${ }^{2}$

Zakat berperan sangat penting dalam meningkatkan kesejahteraan masyarakat, khususnya para mustahiq (penerima zakat). Dalam dana zakat harus mempertimbangkan kebutuhan nyata mustahiq, kemampuan mereka dalam memanfaatkan dana zakat adalah hanya untuk pengembangan kesejahteraan dan bebas dari kemiskinan, sehingga posisi sebagai mustahiq suatu saat dapat beralih menjadi muzakki (pemberi zakat).3 Akan tetapi zakat bertujuan untuk meningkatkan kesejahteraan mustahiq tidak mudah terwujud jika tidak ada andil dari para muzakki dan pengelola zakat. Para muzakki harus menyadari bahwa tujuan berzakat adalah untuk mengentaskan kemiskinan dan tidak hanya semata menggugurkan kewajibannya.

Agar dana zakat dapat dinikmati oleh mustahiq, maka pendistribusian zakat yang baik mutlak diperlukan. Begitupun untuk mendayagunakan zakat dengan sebaik mungkin, dibutuhkan kebijaksanaan dari pemerintah dan pengelola zakat. Dana zakat dapat diberikan dalam bentuk lain yang dapat digunakan secara produktif tidak harus diberikan kepada yang berhak apa adanya . Di zaman Rasulullah sampai zaman setelahnya sudah terbukti bahwa zakat berperan cukup penting dalam meningkatkan kesejahteraan umat.

Berdasarkan UU. Nomor: 23 Tahun 2011 tentang pengelolaan zakat, bahwa organisasi yang berhak mengelola zakat terbagi menjadi dua yaitu: Badan Amil Zakat Nasional (BAZNAS) yaitu organisasi yang dibentuk oleh pemerintah, dan Lembaga Amil Zakat (LAZ) yaitu organisasi yang dibentuk atas prakarsa masyarakat4.

\footnotetext{
1 Yusuf Qardlawi, Kiat Islam Mengentaskan Kemiskinan, (Jakarta: Gema Insani Pers, 1998), 105.

2 Misbahul Munir dan A. Djalaluddin, Ekonomi Qur'anic: Doktrin Reformasi Ekonomi dalam al-Qur'an, (Malang: UIN Malang Press, 2006), 125.

3 Zubaidi, Pemberdayaan Masyarakat Berbasis Pesantren: Kontribusi Fiqh Sosial Kiai Sahal Mahfudh dalam Perubahan Nilai-Nilai Pesantren, (Yogyakarta: Pustaka Pelajar, Cet.I, 2007), 93-94.

${ }^{4}$ Heri Sudarsono, Bank dan Lembaga Keuangan Syariah, (Yogyakarta: Ekonisia,

138 JURNAL LISAN AL-HAL
} 
Untuk meningkatkan daya guna dan hasil guna, zakat harus dikelola secara melembaga sesuai dengan syariat Islam. Distribusi dana zakat adalah salah satu kegiatan yang berhubungan langsung dengan orang-orang yang masih kekurangan dalam hal keuangan. Karena itu distribusi dana zakat memiliki peranan yang cukup besar. Setiap pengelola tidak lepas dari masalah distribusi zakat yang diterima untuk disalurkan kepada masyarakat. Lembaga penerima dana zakat mempunyai hak untuk menentukan kebijakan ditribusi.5

Pendayagunaan zakat dapat diarahkan kepada hal-hal yang bersifat konsumtif dan bersifat produktif.6 Zakat yang bersifat konsumtif adalah dana zakat yang dibagikan kepada mustahiq untuk dimanfaatkan secara langsung dalam memenuhi kebutuhan dasarnya. Sedangkan zakat yang bersifat produktif adalah dana zakat yang diberikan kepada mustahiq sebagai modal untuk menjalankan kegiatan usaha, seperti melalui pendidikan kewirausahaan agar para mustahiq dapat memaksimalkan dana zakat yang diberikan.

Dalam upaya pengumpulan, penyaluran dan pendistribusian zakat, pemerintah dapat menyalurkan melalui beberapa organisasi sosial, seperti Baitul Maal wat Tamwil (BMT) yang merupakan organisasi bisnis yang berperan sosial, yang mempunyai fungsi dan peran dengan Lembaga Amil Zakat.7 Selain BMT ada juga Lembaga Amil Zakat (LAZ), yaitu lembaga pengelola zakat yang dibentuk oleh masyarakat yang pengukuhannya dilakukan oleh pemerintah jika sudah memenuhi syarat-syarat tertentu. Sedangkan Badan Amil Zakat Nasional (BAZNAS), yaitu suatu lembaga pengelola zakat yang dibentuk oleh pemerintah yang personalia pengurusnya terdiri dari ulama', cendekiawan, dan tokoh masyarakat. Selain BMT, BAZNAS dan LAZ, pemerintah juga mengukuhkan beberapa lembaga organisasi sosial diantaranya yaitu Dompet Dhuafa', Rumah Zakat Indonesia dan Pos Keadilan Peduli Umat.

Salah satu lembaga pengelola zakat yakni Badan Amil Zakat Nasional (BAZNAS) Banyuwangi yang dibentuk dalam rangka melayani masyarakat yang hendak menyalurkan Zakat, Infaq dan Shadaqah (ZIS) di wilayah Kabupaten Banyuwangi. BAZNAS Kabupaten Banyuwangi

2004), 240.

5 Fakhruddin, Fiqih dan Manajemen Zakat di Indonesia, (Malang: UIN Malang Press, 2008), 314.

6 Arif Mufriani, Akuntansi dan Manajemen Zakat, (Jakarta: Kencana, 2008), 155.

7 Muhammad Ridwan, Manajemen Baitul Maal wat Tamwil, (Yogyakarta: UII Press, 2004), 126. 
dibentuk oleh pemerintah sebagai pengelola zakat sesuai Surat Keputusan Bupati Banyuwangi Nomor: 188/468/KEP/429.011/2015 Tanggal 16 Oktober 2015.

Pendistribusian zakat yang dilakukan oleh BAZNAS Banyuwangi melalui dua cara. Pertama, penyaluran zakat secara konsumtif, yaitu penyaluran dana zakat yang dilakukan dengan tujuan memenuhi kebutuhan dasar ekonomi para mustahiq berupa pemberian bahan makanan untuk dikonsumsi secara langsung. Kedua, pendistribusian zakat secara produktif sebagai program pemberdayaan ekonomi mustahiq yang dapat dioptimalkan melalui kewirausahaan yang diharapkan dapat menupang keberlangsungan perekonomian mustahiq.

\section{B. Pembahasan}

\section{Sumber Dana Zakat}

Agar supaya menjadi sumber dana zakat atau obyek zakat, harta harus memenuhi beberpa ketentuan. Islam telah membuka kesempatan yang cukup luas, menganjurkan kaumnya untuk mengeluarkan hartanya dengan segala situasi dan kondisi, diantaranya dengan cara infak dan sadakah. Sumber dana zakat tersebut antara lain yaitu:

a. Emas, perak dan uang

Emas dan perak adalah logam mulia yang sering dijadikan perhiasan. Diantara yang tergolong emas dan perak ialah mata uang yang digunakan pada salah satu zaman di masing-masing Negara. Karena itu semua bentuk tempat penyimpanan uang seperti tabungan, Wadiah, deposito, cek, saham, atau surat berharga lainnya, termasuk juga ke dalam kategori emas dan perak. Sehingga cara menentukan nisab dan besarnya zakat disamakan dengan mas dan perak. Jika orang Islam mempunyai emas dan perak, maka wajib dikeluarkan zakatnya jika sampai dengan 1 nisab dan haul yaitu untuk emas 20 dinar sama dengan 85 gram dan nisab perak setara dengan 200 dirham atau sama dengan 672 gram. ${ }^{8}$

b. Harta Perdagangan

Harta perdagangan ialah semua yang diperuntukkan untuk diperjualbelikan dalam berbagai jenis, baik berupa barang seperti alatalat, pakaian, perhiasan. Nisab zakat harta perdagangan sama dengan nisab emas yaitu senilai 85 gram emas, dengan kadarnya zakat sebesar 2,5 $\%$.

${ }^{8}$ Andi Soemitra, Bank dan Lembaga Keuangan Syariah, (Jakarta: Kencana Prenada Media Group, 2012),414.

$140 \mid$ JURNAL LISAN AL-HAL 
c. Hasil pertanian dan hasil perkebunan

Harta hasil pertanian adalah tumbuh-tumbuhan atau tanaman yang memiliki nilai ekonomis seperti halnya biji-bijian, umbi-umbian, sayurmayur, buah-buahan dan lain-lainnya. Nisab hasil harta pertanian adalah 5 wasq atau setara dengan $750 \mathrm{~kg}$.

d. Hasil pertambangan

Harta hasil pertambangan adalah harta yang terdapat di perut bumi yang punya nilai ekonomis seperti halnya timah, tembaga, minyak bumi, batu bara dan lain-lain. Menurut Madzhab Hanafi dan qaul Madzhab Syafi'i bahwa yang dikeluarkan zakatnya sebanyak 1/5. Sedangkan Madzhab Maliki, Syafi'i dan Hambali berpendapat bahwa wajib dikeluarkan zakatnya adalah $1 / 40$.

e. Hasil peternakan

Hasil ternak yang wajib dikeluarkan zakatnya yaitu terdiri dari ternak unta, sapi, kuda, domba atau kambing. Syarat zakat hewan:

1) Sampai 1 tahun (haul)

2) Nisabnya terpenuhi

3) Dipelihara di lapangan tempat terbuka

4) Tidak dijadikan alat untuk bekerja

5) Tidak boleh menyalurkan harta atau binatang yang cacat dan tua (gigi ompong). 9

f. Hasil Pendapatan dan Jasa

Zakat profesi diartikan sebagai zakat penghasilan atau profesi karena telah mencapai nisab. Yang termasuk profesi adalah antara lain pegawai negeri atau swasta, konsultan, dokter, notaris, akuntan, artis, wiraswasta, dan sejenisnya. Sebagian ulama berpendapat, menyamakan zakat profesi sama dengan zakat pertanian, yang dibayar ketika panen, tanpa harus menunggu 1 tahun. Begitu juga mengenai nisab atau ukurannya sebesar 1,350 Kg gabah atau sepadan dengan $750 \mathrm{Kg}$ beras.

Syarat-syarat harta yang menjadi obyek zakat adalah :

a) Harta zakat tersebut diperoleh dari pekerjaan yang halal dan baik, dari substansi benda maupun cara mendapatkannya.

b) Harta zakat tersebut dapat berkembang atau berpotensi untuk dikembangkan. Yusuf Qardhawi berpendapat, bahwa arti berkembang di sini terdiri dari 2 macam, secara konkret dan abstrak. Yang konkret dengan cara dikembangbiakkan, diusahakan untuk berkembang, diperdagangkan, diinvestasikan, dari kegiatan usaha lainnya. Sedang yang abstrak adalah harta yang berpotensi untuk berkembang, baik

\footnotetext{
9 Ibid, 416.
} 
yang berada di tangannya sendiri maupun di tangan orang lain, tetapi atas namanya.

c) Harta penuh milik orang yang berzakat, yaitu harta yang berada di dalam kekuasaan pemiliknya, di dalamnya tidak tersangkut dengan harta dan hak orang lain, ia sendiri dapat menikmatinya, dan mampu mentransaksikan tanpa campur tangan pihak orang lain.

d) Telah mencapai nisab, yaitu jumlah minimal yang menyebabkan harta terkena kewajiban zakat. Penetapan nisab disini sangat penting, karena zakat adalah ibadah yang dibebankan kepada muslim yang mampu untuk diberikan kepada yang tidak mampu. Sedangkan nisab merupakan standar dan indikator yang menunjukkan kemampuan seseorang untuk berzakat.

e) Mencapai 1 haul penuh, ini hanya untuk sumber-sumber zakat tertentu. Yang dimaksud dengan haul adalah harta tersebut sudah berada atau dimiliki atau diusahakan oleh pemiliknya dalam tenggang waktu satu tahun lamanya.10

Jadi, semua ulama' sependapat, bahwa yang menjadi obyek zakat adalah semua harta yang mempunyai nilai ekonomi dan potensial untuk dikembangkan.

\section{Macam-Macam Zakat}

Secara umum zakat terdiri dari 2 macam antara lain:

a. Zakat yang ada hubungannya dengan jiwa manusia yaitu zakat fitrah

Zakat fitrah adalah memberikan sejumlah bahan makanan pokok yang dikeluarkan pada waktu bulan Ramadan oleh setiap muslim baik laki-laki maupun perempuan bagi dirinya dan bagi orang yang ditanggungnya yang memiliki kelebihan makanan pokok untuk sehari pada hari raya Idul Fitri. ${ }^{11}$

Besar dan banyaknya zakat fitrah menurut ukuran zaman sekarang adalah 2,176 kg. Sedangkan makanan atau bahan pokok yang wajib dikeluarkan zakatnya yaitu tepung, terigu, kurma gandum, anggur dan aqith (semacam keju). Untuk Negara yang makanan pokoknya selain 5 makanan di atas, menurut Madzhab Maliki dan Syafi'i membolehkan membayar zakat dengan makanan pokok yang lain. Menurut pendapat Madzhab Hanafi pembayaran zakat fitrah dapat dilakukan dengan membayar harganya dari makanan pokok yang dimakan.

10 Ibid, 120.

${ }^{11}$ Andi Soemitra, Bank dan Lembaga Keuangan Syariah, (Jakarta: Kencana Prenada Media Group, 2010), 413.

142 JURNAL LISAN AL-HAL 
b. Zakat yang berhubungan dengan harta yaitu zakat maal

Menurut syari'at Islam, harta adalah segala sesuatu (benda) yang dapat dimiliki dan dapat digunakan menurut pemakaian yang lazim. Sesuatu dapat disebut dengan maal jika memenuhi 2 syarat, antara lain:

1) Bisa dimiliki, disimpan, diambil dan dikuasai sepenuhnya.

2) Bisa diambil manfaat sesuai dengan kelazimannya. ${ }^{12}$

Zakat harta adalah sebagian harta yang diberikan oleh seorang muslim atau badan yang dimiliki sesuai dengan ketentuan agama untuk diberikan kepada yang berhak menerimanya yang terkumpul ke dalam 8 golongan. Syarat harta yang harus dizakati antara lain milik penuh, berkembang, cukup nisab, lebih dari kebutuhan pokok, bebas dari hutang, sudah berlalu 1 tahun (haul).

Selain penetapan pembagian harta-harta zakat yang tersebut dalam al-Quran, hadis Nabi yang diriwayatkan oleh Bukhari juga menyebutkan macam-macam benda yang harus dikeluarkan zakatnya, antara lain ada 4 bagian:

a. Zakat harta kekayaan yang dinamakan Zakatun Nuqud, yaitu barangbarang emas dan perak, mata uang, uang kertas, cek dan sebagainya.

b. Zakat hewan yang dinamakan Zakatul an Ami, yaitu unta, sapi, kerbau, kambing, dan domba.

c. Zakat perdagangan yang dinamakan Zakatut Tijaroh, yaitu segala macam barang perdagangan.

d. Zakat pertanian yang dinamakan Zakatuz Ziro'ah, yaitu beras, gandum, jagung dan lain-lain. ${ }^{13}$

\section{Hikmah dan Manfaat Zakat}

Zakat merupakan ibadah maaliyah (ibadah dalam masalah harta), mengandung keutamaan dan manfaat yang besar dan mulia yang berkaitan erat dengan orang berzakat (muzakki), penerima (mustahiq), harta yang dikeluarkannya, maupun bagi masyarakat keseluruhan. ${ }^{14}$ Dari beberapa hikmah dan keutamaan zakat itu, dapat dikemukakan sebagai berikut :

a. Menghindari kesenjangan sosial antara orang kaya (muzakki) dengan orang miskin (mustahiq).

12 Sarip Muslim, Akuntansi Keuangan Syariah Teori dan Praktik, (Bandung: CV Pustaka Setia, 2015), 339.

13 Abdullah Zaky Al-Kahf, Ekonomi dalam Perspektif Islam, (Bandung: CV. Pustaka Setia), 129.

14 Heri Sudarsono, Bank dan Lembaga Keuangan Syariah, (Yogyakarta: Ekonisia, 2004), 237. 
b. Pilar amal jama'i antara orang kaya dengan para mujahid dan pendakwah dalam rangka mengagungkan kalimat Allah SWT.

c. Membersihkan dan mengikis akhlak yang buruk.

d. Sebagai alat pembersih harta yang kita miliki dan penjagaan dari ketamakan bagi orang jahat.

e. Ungkapan rasa syukur atas nikmat yang Allah berikan.

f. Pengembangan potensi umat.

g. Sebagai dukungan moral pada orang yang baru masuk Islam (muallaf).

h. Menambah pendapatan Negara untuk proyek dan usaha yang berhasil guna bagi umat. ${ }^{15}$

Selain daripada itu, zakat juga merupakan ibadah yang memiliki nilai dimensi ganda, trasendental dan horizontal. Oleh sebab itu, zakat memiliki banyak keutamaan dalam kehidupan umat muslim, terutama Islam. Zakat memiliki banyak hikmah, baik yang berkaitan dengan Allah SWT. Ataupun berkaitan dengan hubungan sosial kemasyarakatan di antara manusia, antara lain yaitu:

a. Menolong dan membantu dalam membangun kaum miskin dengan materi sekedar hanya untuk memenuhi kebutuhan dasar hidupnya.

b. Menghilangkan penyakit iri hati, rasa benci dan dengki dalam diri orang-orang miskin yang tidak memiliki harta dan tidak ada uluran tangan kepada mereka, sementara di sekitarnya banyak orang-orang kaya berkehidupan cukup, yang bermewah-mewahan.

c. Menjadi unsur yang sangat penting dalam mewujudkan keseimbangan distribusi harta (social distribution), dan keseimbangan tanggung jawab individu umat dalam hidup bermasyarakat.

d. Dapat menunjang berjalannya sistem sosial kemasyarakatan Islam yang berdiri atas prinsip-prinsip pokok: ummatan wahidan (umat yang satu), musawah (persamaan derajat, hak dan kewajiban), ukhuwah Islamiyah (persaudaraan Islam), dan takaful ijti'ma (tanggung jawab bersama).

e. Dapat menyucikan diri dari kotoran salah dan dosa, memurnikan jiwa (menumbuhkan akhlak mulia menjadi murah hati, peka terhadap rasa kemanusiaan) dan mengikis sifat bakhil (kikir) serta serakah. Dengan begitu, akhirnya tercapai suasana ketenangan batin karena terbebas dari tuntutan Allah dan kewajiban kemasyarakatan.

f. Zakat merupakan ibadah yang bersifat harta yang memiliki dimensi dan fungsi sosial ekonomi atau pemerataan karunia Allah serta merupakan

${ }^{15}$ Andi Soemitra, Bank dan Lembaga Keuangan Syariah, (Jakarta: Kencana Prenada Media Group, 2010), 410.

144 JURNAL LISAN AL-HAL 
perwujudan solidaritas sosial, pernyataan rasa kemanusiaan dan keadilan, pembuktian atas persaudaraan Islam, pengikat persatuan umat dan bangsa, sebagai pengikat hubungan bathin antara golongan orang kaya dengan orang miskin dan sebagai penimbun jurang yang menjadi pemisah antara golongan serta antara yang kuat dengan yang lemah. ${ }^{16}$

\section{Sistem Pengelolaan Zakat di BAZNAS Banyuwangi}

Pengelolaan zakat, penghimpunan dan penyaluran zakat merupakan 2 hal yang sama penting. Penghimpunan zakat akan lebih mudah karena orang yang punya kewajiban membayar zakat (muzakki) cenderung mengumpulkan sendiri dari pada menunggu untuk dihimpun petugas zakat. Sedangkan penyalurannya lebih sulit dan membutuhkan berbagai sarana prasarana dan fasilitas serta kegiatan yang menyangkut pendataan dan pengawasan.

Penyaluran (distribusi) dana zakat adalah satu aktifitas atau kegiatan untuk mengatur distribusi sesuai dengan fungsi manajemen dalam upaya menyalurkan zakat dari muzakki untuk mustahiq sehingga tercipta tujuan organisasi secara efektif dan tujuan distribusi dari zakat dapat tercapai dengan baik. Pendistribusian dana zakat pada BAZNAS Banyuwangi kepada para mustahiq dilakukan sesuai dengan syariat Islam dengan mengutamakan kebutuhan dasar mustahiq dengan penyalurannya diatur sebagai berikut:

a. Bantuan dana zakat secara konsumtif, adalah bantuan mustahiq dalam mengurangi masalah kebutuhan dasarnya yang sangat mendesak.

b. Bantuan dana zakat secara produktif, adalah dengan cara membantu mustahiq untuk mengurangi kesulitan ekonomi dalam meningkatkan kesejahteraan baik secara individu atau secara kelompok melalui usaha atau kegiatan yang berkesinambungan.

Untuk memaksimalkan pendayagunaan dana zakat dimaksud diperlukan pengelolaan zakat oleh lembaga amil yang profesional dan mampu mengelola zakat secara baik dan tepat. Pengelolaan zakat akan lebih mudah dengan melalui lembaga pengelola zakat berdasarkan beberapa pertimbangan. Pertama, untuk memastikan kedisiplinan penyaluran dana zakat. Kedua, melindungi perasaan mustahiq apabila bertatap muka langsung untuk menerima zakat dari muzakki. Ketiga, untuk mencapai efektivitas, efisiensi dan tepat sasaran dalam

16 Heri Sudarsono, Bank dan Lembaga Keuangan Syariah. (Yogyakarta: Ekonisia, 2004), 238. 
menggunakan dana zakat dengan mendahulukan skala prioritas yang ada. Keempat, dalam rangka menyebarkan syiar Islam dan pengamalan semangat keadilan sosial dan pemerintahan menurut syariat Islam.

BAZNAS Banyuwangi dalam menjalankan wewenangnya sebagai salah satu badan amil zakat dalam pengumpulan dana zakat, memberikan layanan jemput zakat untuk muzakki yang tidak bisa datang langsung ke kantor BAZNAS. Sementara untuk mustahiqnya, BAZNAS Banyuwangi melakukan langkah door to door dengan mendatangi langsung ke rumahrumah para mustahiq.

Penghimpunan dana zakat dilakukan oleh BAZNAS Banyuwangi bekerjasama dengan Unit Pengumpul Zakat (UPZ) yang ada di masingmasing kecamatan, hal ini dilakukan agar mustahiq di seluruh Banyuwangi dapat menerima dana zakat tersebut untuk meningkatkan taraf ekonominya.

Muzakki dapat memberikan dan mengumpulkan dana zakat secara langsung ke kantor BAZNAS Banyuwangi ataupun melalui rekening bank yang telah disediakan oleh BAZNAS. Sedangkan untuk mustahiq, BAZNAS Banyuwangi memberi bantuan dengan cara langsung atau door to door agar mustahiq merasa lebih dihargai dan merasa senang terhadap bantuan dana zakat dari BAZNAS Banyuwangi.

Zakat yang sudah terkumpul di BAZNAS Banyuwangi selanjutnya didistribusikan langsung kepada para mustahiq, setelah sebelumnya mereka memenuhi prosedur yang telah ditentukan. Dalam hal ini BAZNAS Banyuwangi melakukan pendistribusian zakat untuk mustahiq berdasarkan:

a. Hasil penelitian dan pendataan mustahiq 8 golongan.

b. Mengutamakan mustahiq yang paling tidak mampu serta yang sangat perlu untuk dibantu.

c. Mengutamakan mustahiq dalam satu daerah.

Sebagaimana yang telah ditetapkan oleh syariat Islam, bahwa yang berhak menerima zakat, BAZNAS Banyuwangi memberikan penyaluran zakatnya kepada fakir, miskin, para amil, muallaf, gharimin, sabilillah dan ibnu sabil. Untuk riqob (budak) tidak dimasukkan pada mustahiq karena di wilayah Banyuwangi tidak ada riqob.

BAZNAS Banyuwangi mendata, meneliti 8 asnaf se Kabupaten Banyuwangi dengan mengadakan koordinasi dengan UPZ yang ada di seluruh kecamatan dengan mengisi formulir data secukupnya yang kemudian formulir tersebut didistribusikan ke Badan Amil Zakat kecamatan, mengadakan klasifikasi mustahiq berdasarkan kelompok asnaf

$146 \mid$ JURNAL LISAN AL-HAL 
dan skala prioritas pemberian bantuan, baik bantuan konsumtif maupun bantuan produktif. Dari terkumpulnya formulir dan pengklasifikasiannya akan disusun data base mustahiq untuk pengambilan kebijakan-kebijakan selanjutnya.

Pendistribusian yang baik didapatkan dengan memastikan bahwa golongan yang berhak menerima dan yang tidak berhak menerima dipastikan tidak mendapatkan bagian. Kaidah lain yang diperlukan dalam pendistribusian zakat adalah adil dalam pembagian, yang dapat ditempuh melalui cara memberikan hak zakat kepada seluruh ashnaf (kelompok penerima), jika harta zakat banyak, dan jika ada kesamaan kebutuhan.

Zakat yang sudah dihimpun oleh badan atau lembaga zakat dari para muzakki didistribusikan pada yang berhak menerimanya. Adapun kriteria dari ke delapan asnaf tersebut sebagai berikut:

a. Fakir; orang yang lemah ekonomi dan lemah potensi ekonomi

b. Miskin; orang yang lemah ekonomi tapi tidak lemah potensi ekonomi artinya masih mempunyai potensi yang dapat dikembangkan

c. Amil; orang yang bekerja pada sektor pengelolaan zakat, dan dia diangkat oleh pemerintah atau pihak yang mendapat kewenangan dari pemerintah

d. Sabilillah; relawan jihad /orang yang berjuang dijalan Allah

e. Ibnu Sabil; orang yang sedang kehabisan bekal di perjalanan dan putus dari asset yang dimiliki

f. Gharim; orang yang terlilit hutang dan tidak memiliki kemampuan untuk melunasinya

g. Muallaf; orang yang dilunakkan hatinya, dari kalangan yang baru masuk Islam

h. Riqob; orang yang terjerat otoritas yang membelenggu dan ada peluang membebaskannya.

Mendayagunakan hasil pengumpulan zakat kepada 8 asnaf sebagai mustahiq baik yang bersifat konsumtif maupun bersifat produktif seperti bantuan beasiswa kepada anak yang berprestasi dan kurang mampu secara ekonomi untuk membiayai sekolahnya. Pemberian bantuan sarana/modal produktif yang bisa berke-sinambungan kepada mustahiq yang tidak mampu tetapi telah mempunyai usaha kecil seperti modal usaha bagi pedagang nasi atau yang lainnya.

BAZNAS Banyuwangi bekerja secara profesional dan dituntut untuk memiliki data muzakki dan mustahiq yang valid, penyampaian laporan keuangan kepada masyarakat secara transparan, diawasi oleh akuntan publik, dan memiliki amilin atau sumber daya manusia yang profesional, serta program kerja yang dapat dipertanggung jawabkan. Disamping itu 
pengelolaan zakat juga ditunjang oleh penggunaan teknologi informasi untuk memudahkan pengelolaan dan pengorganisasian dana zakat.

Jadi sistem pengelolaan zakat yang ada di BAZNAS adalah mengumpulkan dana ZIS terlebih dahulu daripada dana zakat. Jika sudah terkumpul dan dianggap sudah waktunya untuk disalurkan, maka pengelola zakat mengadakan rapat koordinasi dalam rangka menetapkan mustahiq penerima zakat. Penentuan mustahiq dimaksud didasarkan pada pengajuan proposal yang diterima pengelola zakat dan masukan dari muzakki sebagai pemberi dana zakat.

BAZNAS Banyuwangi mempunyai beberapa aturan dalam pendistribusian zakat, yaitu :

a. Sebelum dana zakat didistribusikan, semua pengurus melakukan rapat komisioner terlebih dahulu untuk menentukan mustahiq yang akan diberi dana zakat, layak atau tidak sesuai proposal yang diajukan oleh Unit Pengelola Zakat.

b. Setelah proposal dirapatkan, para komisioner menentukan berapa jumlah dana atau bantuan yang akan diberikan kepada mustahiq.

c. Dana zakat kemudian didistribusikan langsung kepada 8 asnaf secara door to door.

Mekanisme ini untuk memberikan tenggang waktu kepada BAZNAS Banyuwangi dalam mengumpulkan besaran potensi zakat dan untuk mencari orang-orang yang berhak menerima zakat atau mustahiq, sehingga BAZNAS dapat mengelola dana zakat dengan baik.

\section{Peran BAZNAS Banyuwangi dalam meningkatkan kesejahteraan mustahiq}

Ibadah zakat adalah ibadah yang merupakan perintah Allah yang berkaitan dengan harta benda. Kita yakin bahwa jika setiap perintah Allah itu dilaksanakan pasti akan membawa dampak positif atau maslahat bagi orang yang melaksanakannya. Dengan zakat ini kiranya dapat mengurangi kaum fakir miskin dan mustahiq yang terdapat di setiap desa atau bahkan di kota sekalipun. Melalui zakat pula diyakini umat Islam akan menjadi kuat baik secara materi ekonomi ataupun mental.

Jika dilihat dari segi penerimaannya, zakat memiliki misi yaitu meningkatkan kesejahteraan umat Islam sehingga terpenuhinya kebutuhan hidup manusia, baik secara primer maupun sekunder. Untuk terciptanya kesejahteraan itu, maka lebih dahulu dibangun adalah sikap mentalnya agar bermental produktif yang mempunyai sumber dana untuk mengembangkan kebutuhan hidup.

$148 \mid$ JURNAL LISAN AL-HAL 
Disamping untuk mendidik sifat dermawan, zakat juga merupakan salah satu wujud syukur atas harta yang telah dianugerahkan Allah kepada manusia, di samping itu juga sebagai bahan pembelajaran agar manusia dapat melakukan sedikit pengorbanan kepada orang-orang yang tidak mampu dengan cara mengeluarkan zakat.

Pemberian bantuan zakat yang diberikan kepada mustahiq pada dasarnya adalah untuk membantu mustahiq dari kemiskinan, atau dari kekurangan untuk memenuhi kebutuhannya. Perubahan taraf ekonomi yang terjadi kepada mustahiq setelah diberikannya bantuan dana zakat sebenarnya dapat dilihat melalui beberapa indikator ekonomi yang dirasakan oleh mustahiq. Pertama, melalui bantuan yang diberikan dapat memenuhi kebutuhan sehari-hari mustahiq. Hal tersebut apabila distribusi yang diberikan bersifat konsumtif, sehingga dapat digunakan mustahiq sebagai pemenuhan kebutuhan ekonomi dasarnya, yang dikenal dengan pangan.

Kedua, bantuan zakat dapat meningkatkan taraf ekonomi mustahiq, terlebih dapat merubah status mustahiq menjadi muzakki. Karena hal tersebut benar-benar membuktikan bahwa bantuan dana zakat yang diberikan membawa manfaat dan berguna bagi mustahiq, dimanfaatkan secara maksimal dan dapat menjalankan usaha sesuai dengan apa yang diharapkan oleh mustahiq.

BAZNAS Banyuwangi menjalankan perannya dengan memberikan penyuluhan-penyuluhan kepada masyarakat terutama masyarakat yang mampu membayar zakat (muzakki) tentang pentingnya potensi zakat. Agar masyarakat tahu bahwa besaran potensi zakat dapat membantu program pemerintah dalam mengentaskan kemiskinan, juga memberikan bantuan modal sebagai dana bergulir kepada mustahiq dan pedagangpedagang kecil dengan tidak memakai bunga.

Selain itu, memberikan bantuan sandang pangan melalui uang atau zakat yang telah terkumpul oleh BAZNAS, serta memberikan bantuan biaya sekolah kepada yang tidak mampu dan memberikan program beasiswa bagi siswa yang berprestasi, serta memberikan bantuan pengobatan kepada mustahiq yang sakit yang tidak mempunyai biaya.

Bantuan yang diberikan oleh BAZNAS Banyuwangi baik berupa konsumtif ataupun produktif kepada mustahiqnya telah mampu meningkatkan taraf ekonomi mustahiq. Hal tersebut dapat dibuktikan dengan sampel mustahiq yang menggambarkan bahwa keadaan ekonomi mustahiq mengalami peningkatan. Dari mustahiq yang telah diteliti, membuktikan keadaan mustahiq membaik bahkan ada yang mengalami kemajuan, walaupun ada beberapa mustahiq yang menunjukkan tingkat 
ekonominya masih tetap.

\section{Simpulan}

Distribusi dana zakat dari BAZNAS Banyuwangi dalam meningkatkan kesejahteraan mustahiq sudah baik. Hal ini terbukti dalam menyalurkan zakat, sudah sesuai dengan Syariat Islam, zakat yang diberikan kepada mustahiq terdiri dari 8 golongan (asnaf) yaitu fakir,miskin, amil (pengelola zakat), muallaf, gharimin, fi sabilillah, budak dan ibnu sabil. Akan tetapi zakat tidak tersalurkan kepada 1 golongan yaitu budak (riqob) karena di Kabupaten Banyuwangi tidak ada budak (riqob). Adapun bentuk penyalurannya bisa bersifat konsumtif, yaitu memberikan zakat kepada mustahiq dalam rangka mengurangi beban dasar ekonominya yang sangat mendesak, dan bantuan secara produktif yaitu membantu mustahiq untuk meningkatkan kesejahteraan baik secara perorangan maupun kelompok melalui kegiatan pengembangan ekonomi dan kewirausahaan yang sudah ada di BAZNAS Banyuwangi.

Peran BAZNAS Banyuwangi dalam meningkatkan kesejahteraan mustahiq dijalankan melalui: memberikan penyuluhan-penyuluhan kepada masyarakat terutama masyarakat yang mampu membayar zakat (muzakki) tentang pentingnya potensi zakat. Hal ini dilakukan agar masyarakat tahu bahwa besaran potensi zakat dapat membantu program pemerintah dalam mengentaskan kemiskinan, memberikan bantuan sandang pangan melalui uang atau zakat yang telah terkumpul oleh BAZNAS, memberikan bantuan biaya sekolah kepada keluarga yang tidak mampu dan memberikan program beasiswa bagi siswa yang berprestasi.

\section{DAFTAR PUSTAKA}

Al-Arif, M.Nur Rianto. Pengantar Ekonomi Syariah Teori dan Praktik, Bandung: CV Pustaka Setia, 2015.

Al-Kaaf, Abdullah Zakiy, Ekonomi dalam Perspektif Islam, Bandung: CV Pustaka Setia, 2002.

Al-Zuhaili, Wahbah, Zakat Kajian Berbagai Madzhab, Bandung: PT Remaja Rosda Karya, 2000.

Amalia. "Jurnal Ekonomi dan Keuangan", Potensi dan Peranan Zakat Dalam Mengentaskan Kemiskinan di Kota Medan, Vol.1, No.1 Juni, 2012.

Arikunto, Suharsimi. Prosedur Penelitian Suatu Pendekatan Praktek, Jakarta: PT. Rineka Cipta, 1986.

$150 \mid$ JURNAL LISAN AL-HAL 
Arsyianti, Dwi Laily Dan Irfan Syauqi Beik, Ekonomi Pembangunan Syariah, Jakarta: PT Raja Grafindo Persada, 2016.

Asnaini, Zakat Produktif Dalam Perspektif Hukum Islam, Yogyakarta: Pustaka Pelajar Offset, 2008.

Asnawi, Nur Dan Masyhuri. Metodologi Riset Managemen Pemasaran. Malang: UIN Malang Press, 2009.

Chaundry, Muhammad Sharif. Sistem Ekonomi Islam Prinsip Dasar. Jakarta: Prenada Media Group, 2016.

Fakhruddin, Fiqih dan Manajemen Zakat di Indonesia, Malang: UIN Malang Press, 2008

Hafidhuddin, Didin, Zakat dalam Perekonomian Modern, Jakarta: GemaInsani Press, 2012.

Hasanah, Umrotul, Management Zakat Modern, Instrument Pemberdayaan Ekonomi Ummat, Malang: UIN Malik Press, 2010.

Karim, Adiwarman A., Ekonomi Mikro Islam, Jakarta: PT Raja Grafindo Persada, 2003.

Lubis, Irsyad dan Siti Halida Utami, "Jurnal Ekonomi dan Keuangan", Pengaruh Pendayagunaan Zakat Produktif Terhadap Pemberdayaan Mustahik di Kota Medan, Vol 2, No. 6 Juni, 2013.

Mahmudi, Sistem Akuntansi Organisasi Pengelola Zakat, Yogyakarta: P3EI, 2009.

Mufriani, Arif, Akuntansi dan Manajemen Zakat, Jakarta: Kencana, 2008.

Munir, Misbahul dan A Djalaluddin, Ekonomi Qur'ani: Doktrin Reformasi Ekonomi dalam Al-Qur'an, Malang: UIN Malang Press, 2006.

Muslim, Sarip, Akuntansi Keuangan Syariah Teori dan Praktik, Bandung: CV Pustaka Setia, 2015.

Muthaher, Osmad, Akuntansi Perbankan Syariah, Yogyakarta: Graha Ilmu, 2012.

Qordhawi, Yusuf, Spectrum Zakat dalam Membangun Ekonomi Kerakyatan, Jakarta: Zikrul Hakim, 2005.

Ridwan, Muhammad, Manajemen Baitul Mal Wat Tamwil, Yogyakarta: UII Press, 2004.

Rozalinda, Ekonomi Islam, Jakarta: PT Grafindo Persada, 2015.

Soemitra, Andi, Bank dan Lembaga Keuangan Syariah, Jakarta: Kencana Prenada Media Group, 2012.

Sudarsono, Heri, Bank Dan Lembaga Keuangan Syariah, Yogyakarta: Ekonisia, 2004.

Syafa'at, Abdul Khaliq, "Jurnal Penelitian Sosial Keagamaan", Potensi Zakat Infaq Shadaqah Pada Badan Amil Zakat Nasional Di Kabupaten Banyuwangi. Vol. 9, No.1 Juni, 2015. 
Thoriquddin, Moh., Pengelolaan Zakat Produktif Prespektif Maqosif As Syariyah, Malang: UIN Maliki Press, 2015

Widodo, Hertanto, Akuntansi dan Manajemen Keuangan Untuk Organisasi Pengelola Zakat, Ciputat: Institut Manajemen Zakat, 2011.

$152 \mid$ JURNAL LISAN AL-HAL 